\title{
ポートフォリオ・システムによる「一般教育」 プログラムのための全体的評価方法の開発
}

Development of a Holistic Assessment Tool of e-Portfolio System for General Education Program

\author{
夏 目 賢 一 ${ }^{* 1}$ \\ Kenichi NATSUME
}

\begin{abstract}
At Kanazawa Institute of Technology (KIT), a new e-portfolio system "Engineering Ethics Portfolio" was developed as a holistic assessment tool to assess the outcomes of engineering ethics education. This new system is expected to analyze the successive effects of our entire general education program especially that of its three core required courses. This new tool is also aimed at preparing for the international trend of quality assurance. To develop an effective well-balanced program, we need to evaluate our whole program with its original criteria. KIT has already developed a "Self-evaluate Portfolio" in "KIT Portfolio System." This new assessment tool was made from modifying the existing portfolio. This article reports and discusses this new approach.
\end{abstract}

Keywords: Quality Assurance, Program Evaluation, Engineering Ethics, General Education, AHELO, DeSeCo

キーワード：質保証，プログラム評価，技術者倫理，一般教育，AHELO，DeSeCo

\section{1.まえがき}

近年，高等教育の質保証に対する社会的な要求が高 まっている，そのための一般的な指標として，世界的 には OECDの AHELO や DeSeCo といった学習成果や 能力についての評価項目が定められ，日本国内では学 士力や社会人基礎力といった指針が導入されている. これらは，高等教育のユニバーサル化とグローバル化 を背景とした世界的な動向であり，JABEEの設立に よる技術者教育プログラムのアクレディテーション も，この動きの中に位置づけることができる ${ }^{1)}$.

これらのプログラム評価においては，プログラム全 体に対するアカウンタビリティを高め，それを教育改 善に結びつけていくことが求められている. そして, 米国のABETなどに見られるように，プログラム全 体に対するアウトカム評価を具体化していくことが求 められるようになっている ${ }^{2)}$. ある教育機関で，その 教育理念ないし目的に基づいて科目構成がなされたと しても，それはあくまでも理念上でのことであって， プログラム全体の実際の教育におけるその理念の実現 が必ずしも保証されるわけではない，そのため，科目 ごとではなくプログラム全体に共通する項目に基づい て，その各科目を統一的に評価する意義が生じる.

筆者は，以上の現状を踏まえて，金沢工業大学にお

平成 23 年 3 月 15 日受付

※ 1 金沢工業大学
ける「一般教育 (General Education：教養教育)」プ ログラムにおける必修科目についての教育効果の測 定・評価方法の開発を㧍こなった，とくに工学系の限 られた一般教育科目においては，よりバランスのとれ た教育内容を保証し，教育効果を高めていくことが求 められる。 そこで, 本研究では, 平成19年度特色 GP「価 值の共有による技術者倫理教育」の助成を受けて「技 術者倫理ポートフォリオ」という独自のシステムを開 発し, 特色 GPプロジェクトの目的でもある技術者倫 理教育を全学的に展開する EAC (Ethics Across the Curriculum）のさらなる推進を目指すことになった.

なお，今回報告する評価項目は，あくまで技術者倫 理に関連したものであるが，後述するように，「一般 教育」についてのプログラム評価を念頭に置いたもの である。本論文では，この新しく開発した方法につい て, その概要を報告し, 今後の展開に向けた考察を加 えたい.

\section{2. 技術者倫理ポートフォリオの方法}

\section{1 評価の目的}

金沢工大では，平成21年度時点の修学基礎教育課程 （一般教育科目群）の必修科目として，1 年次から 3 年次にかけて「技術者入門 I, II, III」( 1 年次：各 $1 / 2$ 学期間）「日本学 $A, B 」(2$ 年次 : 各 $1 / 2$ 学期間 $)$ 「科学技術者倫理」（3 年次： 1 学期間）の三種類の科 目が実施されている.それぞれの目的は,「技術者入門」 
が技術者という職業を社会の動向と関連づけて理解す ることであり，「日本学」が日本の歴史・文化を学ぶ ことで日本人としての自覚を形成することであり,「科 学技術者倫理」が技術者として直面する倫理的問題を 学び，そのような問題を解決していく能力を高めるこ とである。このように，それぞれの必修科目は基本的 に異なる目的を持っている。そそのため，これらの科目 では, 各担当者によって授業内容が定められ, 成績評 価の評価項目も設定されている。

このように科目ごとに評価項目が異なることは，そ の科目で目標とされた学習成果について学生の単位認 定をおこなうためには合理的であるし必要不可欠であ る。しかし，科目ごとに評価項目が異なることは，そ れぞれの授業の教育効果をプログラム全体で評価する ことには適さず，教育プログラム全体として意図され ている学習成果を検証することには十分に寄与しな い. そのため, 金沢工大の一般教育プログラムそのも のを評価するための新しい方法が必要となる.

そこで今回, 技術者倫理ポートフォリオの開発に よって，これらの必修科目を通じて学生が得た学習成 果を学生自身が技術者倫理という観点から自己評価で きるようにした，そして，大学側からもプログラム全 体の教育効果を測定・評価することを可能とするため の機能を実装することを目指した。

この目的のために，まずは上記の必修 3 科目で共通 する評価項目・基準を設定した，次に，その評価項目 の妥当性を保証するために，それらと課程や大学全体 の教育目標とを関連づけ, さらには OECDなど大学 外部で提唱される項目とも関連づけることを試みた. そして，それらの評価結果と現状の教育プログラムの 学習成果との整合性を分析することで，金沢工大の一 般教育に生じている特徵や偏りを明確にすることを目 指した，それによって，科目ごとの内容の変更だけで なく, 開講時期の変更や科目の入れ替えなども視野に 入れた，プログラム全体のバランスを考慮した科目内 容の改善を検討するための参考資料が得られることを 期待した。

なお，教育プログラムの評価にポートフォリオを利 用することは，例えば米国のローズ・ハルマン工科大 学で進められている ${ }^{3)}$ 。筆者も，2009年に同校で開催 された教育評価のための学会 (RosEvaluation Conference）に参加し，技術者倫理ポートフォリオの開発を 進める上で有用となる様々な知見を得た。

\section{2 評価項目}

評価をおこなう上で，まずはそのための評価項目を 定める必要がある。今回は,「一般教育」プログラム と結びつけて評価するために, 評価の基礎となる「技 術者倫理」には金沢工大独自の広義の解釈として「教 養」に近い意味が与えられることになった。この前提 の下で各科目担当者の協力を得て, 必修 3 科目で共通
する学習教育目標を定めた。これを表 1 に示す。なお， 表中にある「KIT-IDEALS」とは，金沢工大におけ る行動規範の名称のことである.

さらに, 修学基礎教育課程の学習・教育目標, およ びAHELO とDeSeCoの評価項目については, 表 2 お よび表 3 のように整理した。 そして最終的に，これら の内容に基づいて, 技術者倫理ポートフォリオでの分 析に用いる評価項目を表 4 のように定めた。 ここで, 表 4 の（1）から (5) の項目を, 表 1 から表 3 のそれぞ れの項目と表 5 のように対応づけた.

\section{3 技術者倫理ポートフォリオの機能}

次に, この技術者倫理ポートフォリオによる評価方 法の仕組みを説明する。

金沢工大では, 「KIT・ポートフォリオ・システム」

\section{表 1 金沢工大「技術者倫理」の評価項目}

\section{1. 共有すべき価値（広義）}

1-a. 価值についての総合的理解

- 価值およびその多様性に関する理解：文化に対する評価 軸の形成, 文化, 市場経済, 国家などの地球規模での展 望やグローバリゼーションの理解

1-b. 社会を構成する基本概念の理解

- 法や経済など社会制度の理念の理解 : 権利と義務いう概 念の形成や, 民主主義と基本的人権, 資本主義と財産権 などの西洋的概念の導入過程など

- 法と憲法との関係, その成立過程や倫理規範, 近代国家 概念との関係,「国民」の形成と法など

1-c. 技術者として社会から求められる資質の理解

- 大学全体の教育と外部の制度との関連を踏まえて

$1-d-1$. 金沢工業大学の全学としての教育理念への対応

- KIT-IDEALSに示された価值群の理解

1-d-2. 修学基礎教育課程の教育目標への対応

- 人間力, 社会人基礎力など, 必要最低限とされる項目 $1-\mathrm{d}-3$. 各学科の教育目標への対応

2. 共有すべき価值（狭義）

2-a. 公衆の安全・健康・福利の最優先（人類の幸福に関す る考察・理解を含む）および，社会に対して優先される 価值観の歴史的変遷と，その価值（観）に対する技術者 のとるべき態度

- ある社会的役割を担う集団の社会的意識の形成, 他の集 団・公共性への配慮

$2-b$. 専門職としての社会への貢献

- 市民社会・消費者・公共性についての理解

$2-$. 科学技術の成果が社会に与える影響（新しい価值の創 出を含む) の理解, 技術との関わり, 異文化との融合

$2-\mathrm{d}$. 自然環境への視点・態度, 地球環境に対する責任

- 持続可能性, 地球的視野からの判断と行動

$2-\mathrm{e}$. 倫理と法の関係

- bとは異なり, 法律についての個別具体的な解説

2-f. 依頼主・雇用主に対する責任,「契約」に対する態度, 技術者の責任に対する態度と社会的評価，社会契約とい う概念の歴史的意味

3. 行動設計能力の育成

3-a. 責任ある研究 (誠実, 正直, 正確, 効率〈無駄の排除〉) への理解, 研究上の不正 (捏造, 改ざん, 剽窃) 防止 · 回避

3-b. 倫理的判断能力 / 意思力などの育成

$3-$ c. 自己研鑽

- 学生として重視すべき価值, 自学自習など 
表 2 金沢工大 · 修学基礎教育課程の学習 - 教育目標

\begin{tabular}{|l|}
\hline 1. 能動的な学習・生活スタイルの習得 \\
\hline 2. 技術者として必要な素養の習得 \\
\hline $2-a$. 倫理観 \\
$2-b$. 使命感 \\
$2-c$. 国際感 \\
$2-$ d. 歴史観 \\
\hline 3. 社会人としての基本的なコミュニケーション能力 \\
\hline
\end{tabular}

表 3 AHELOおよびDeSeCoの対応項目

\begin{tabular}{|l|}
\hline 1. AHELO \\
\hline $\begin{array}{l}\text { 1-a. 社会・健康・安全・環境・商業といった制約に配慮. } \\
\text { (Engineering Analysis) }\end{array}$ \\
1-b. 健康・安全・法規則への理解, 業務上の責任, 社会 \\
や環境への影響, 専門職倫理・技術業における責任と \\
規範の重視, などを実践する. (Engineering Practice) \\
\hline 2. DeSeCo \\
\hline 2-a. 相互作用的に道具を用いる \\
2-b. 自律的に活動する \\
2-c. 異質な集団で交流する
\end{tabular}

を構築して，学生が各自の学習過程とその成果につい ての分析と管理を進め，それぞれのキャリアの自己実 現を支援するための体制を整えてきた ${ }^{4)}$. この既存の ポートフォリオ・システムの中に，履修した各科目の 修了時に学生がその科目での達成度を自己評価し, そ れを学内ネットワーク上に記録するためのシステムを 設けて，それを「自己評価レポート・ポートフォリオ」 と名づけている。本論文で報告する技術者倫理ポート フォリオは, この既存の自己評価レポート・ポートフォ リオを利用することで開発したものである.

まず，自己評価レポート・ポートフォリオには，そ れぞれの科目において学生によって入力されたデータ がすでに存在している. 技術者倫理ポートフォリオの システムでは，この自己評価レポート・ポートフォリ オとして保存されているデータ・テーブルの, 評価項 目に対応するフィールドを選択して, 検索対象として 設定する機能を設けた。 なお，この選択は多対多で設 定できるようにした.

そして，この自己評価レポート・ポートフォリオの テーブルを対象として，クエリーを作成できるように した.このクエリーでは, 学年・学科, 対象設問, キー ワードといった限定条件を任意に設定できるようにし た. 例えば, グローバル化という検索キーを入れれば, そのキーワードのあるデータのみを選別することがで きる。

次に, これらの作業を効率よくおこなうための画面 を新規作成した。このクエリーのための設定画面が図 1 （上）のようになり，その検索結果は図 1 (下）の ように表示される.

ここで，データの検索をおこなうにあたっては，検
表 4 技術者倫理ポートフォリオの評価項目

（1）価值観や文化の多様性を理解している

- 一つの価值観（視点）にとらわれず,他の価值観（視点） にも配慮し，それらのバランスの中で自分の考えを表 現できている.

- ここでの価值観とは，安全性や経済性などの一般的な ものでよく，国際性と関係している必要はない.

(2) 国際感覚を有している

- 日本という国家，あるいは国際社会を意識している。

（3）現代社会の基本概念について理解している

- 社会一般を構成している基本概念について理解してい る.

- 社会における規範の存在を理解している.

（4）科学技術の社会への影響力について理解している

- 高度に専門化した科学技術が社会に及ぼす複雑な影響, 例えば環境問題のメカニズムを理解し，現在どのよう な社会的対応がとられているか理解している。

（5）責任感を有している

- 技術者として社会から求められている資質を理解し, それらを自身において実現しようとする意志が認めら れる。

・ 行動に結びつけようとする意識があるかどうかが判断 基準となる.

- 規範的内容が書かれており, さらに本人の実行への意 志が読み取れるもの.

\section{表 5 各評価項目の対応関係}

\begin{tabular}{|l|l|l|l|}
\hline & \multicolumn{1}{|c|}{ 必修科目 } & \multicolumn{1}{|c|}{ 課程 } & \multicolumn{2}{|c|}{ AHELO, DeSeCo } \\
\hline$(1)$ & $1-a, 2-c$ & $2-a$ & $1-a, ~ 1-b, 2-a, 2-b$ \\
\hline$(2)$ & $1-a, 2-c$ & $2-c$ & $1-a, ~ 1-b, 2-c$ \\
\hline$(3)$ & $1-b, 2-a, 2-e$ & $2-d$ & $1-a, ~ 1-b, 2-c$ \\
\hline$(4)$ & $\begin{array}{l}1-c, 2-a, 2-c, \\
2-d\end{array}$ & & $1-a, 1-b, 2-a$ \\
\hline$(5)$ & $\begin{array}{l}1-c, 2-b, 2-f, \\
3-a\end{array}$ & $2-a, 2-b$ & $1-b, 2-b, 2-c$ \\
\hline
\end{tabular}

索されたデータの全数が表示されるようにし, さらに 評価の作業を効率化するために，その中から抽出する データの件数も指定できるようにした．抽出件数を指 定した場合には, 抽出データが乱数で無作為に選別さ れるようにした。

なお，この技術者倫理ポートフォリオでおこなう評 価は教育プログラムに対する評価であり, 学生個人に 対する成績評価ではない. そのため, 学生個人を特定 できる情報は検索結果のデータからは除外し，データ はすべて匿名の状態で扱われるようにした。

そして，分析をおこなうためのデータはCSV 形式 の電子ファイルで出力できるようにして汎用性を持た せ，このデータの分析を大学外の業者に委託すること にした，このように外部委託をおこなう理由は，分析 の中立性を担保するためである，もし，この評価をプ ログラムの関係者がおこなった場合には，その利害関 係が評価に反映されかねない，そうすると，プログラ ム全体の科目間のバランスを評価する上で, その評価 に何らかの偏りが生じてしまうことが予想される，今 

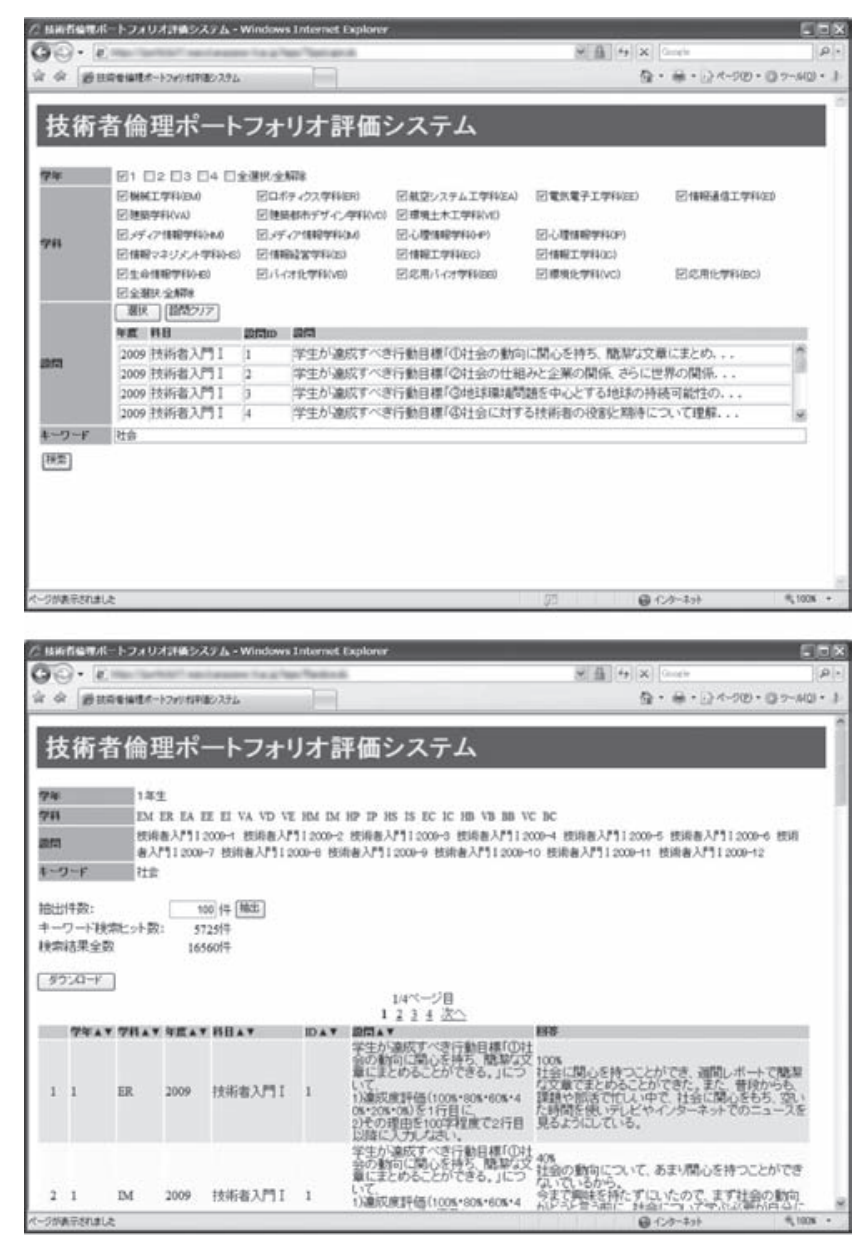

図 1 検索設定画面（上）と結果表示画面（下）

回の評価では, 科目とプログラム全体との関係に対す る教員の認識そのものが評価の対象となる. そのため, デー夕分析の外部委託は必須であると判断した。

また，評価にあたっては，採点者間信頼性（IRR： Inter-rater Reliability) を確保するために, 複数の評 価者によって評価をおこなう必要があると考えた。そ のため, 今回は 3 名の評価者によって独立して分析を 進めるように業者に依頼した。

もちろん，評価をおこなう前には評価基準を共通確 認する必要があるため，これも合わせて依頼した，具 体的には，各ファイルを評価する上で，最初の三つの 設問回答について各評価者が評価を书こない，その評 価の理由について情報共有をおこなう。そここで, 評価 ないし意見が一致しなかった場合には，簡単な協議に より評価者全員が納得できる基準を模索することとし た、ただし，それでも意見が一致しないようであれば 多数決によりその基準を決定することとした. そして, その基準にしたがって, 残りの回答について各評価者 により評価を進めることとした。

\section{3. 分析}

以上の方法を用いて，実際のデータ分析を次のよう に進めた。

まず，データの抽出を抢こなった，今回は，予算上
の制約もあり，それぞれ100件のデー夕を抽出するこ とにした（もちろん, 次で説明するキーワードによっ ては, 抽出件数が100件に満たない場合もありうる.）

データの抽出方法としては,「設問固定型抽出」と「設 問横断型抽出」の二種類の方法を実施した．前者の「設 問固定型抽出」とは，評価の対象として適当な設問を 選択し，その設問回答のデータを無作為に抽出する方 法である。この場合には, 抽出の際にキーワードは設 定しない. それに対して後者の「設問横断型抽出」と は，該当科目のすべての設問回答について特定のキー ワードを設定し，そのキーワードを含む回答デー夕を 任意に抽出する方法である.例えば,「社会」というキー ワードを設定し，文章の中にそのキーワードを含む設 問回答を選択して，その文脈から価值観の多様性など を評価する。

そして，このようにして抽出したデー夕に対して， 表 4 の 5 項目についての評価を実施した。 ここで, 評 価の基準は, 次の $(\mathrm{A})$ から $(\mathrm{F})$ の 6 段階に設定した。

【評価基準】

（A）質問項目にはない独自の言葉を十分に用いてお り，その能力を十分に有していると認められる.

(B) 質問項目にはない独自の言葉も取り入れて説明 しており，その能力を有していると認められる。

(C) 説明不十分ないし説明が一部不適切であるな ど，その能力を有しているとは認められない.

（D）内容の䛊解・論理矛盾・意味不明な説明であり, 誤った理解ないし理解の欠如が認められる。

（E）評価項目と設問の内容との関連性が低く, 判定 不能.

（F）質問の繰り返しであり，独自の言葉を用いてお らず, 判定不能.

ここで，評価の作業手順としては，まずは $(\mathrm{F})$ であ るかどうかを判断することになる，次に，設問内容を 参照しながら (E)であるかどうかを判断する.さらに, 文章の意味内容の正誤や論理性から (D) を判断する. その上で，(B)を標準的としてそれとの関係で，(A) から $(\mathrm{C})$ を判断するという手順を踏むことにした。た とえある項目で $(\mathrm{F})$ と判定されても, 他の評価項目で は (F) 以外の判定がつくことは十分にありうる.また, (E) は設問と評価の対応の問題であり, 科目設計の問 題であって学生の問題ではない可能性が高い. それに 対して, (A) から (D) ないし (F) は学生の能力の問題 である可能性が高い. とくに (A) から (D)について は学生の評価項目内容についての能力ないし学習成果 の問題であると判断できる.

な押, 自己評価レポート・ポートフォリオには達成 度の割合 $(\%)$ も学生本人による自己評価として記入 されている，もちろん，この自己評価の值は評価にあ たっては何ら考慮しないこととした，ただし，この本 人の自己評価も最終的な考察の参考のために合わせて 
表 6 一つの抽出デー夕に対する評価例

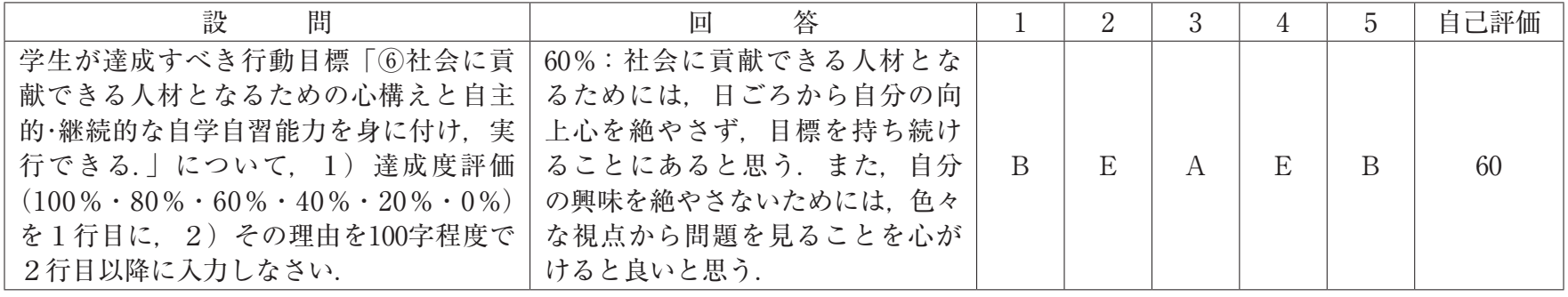

記載することとした。この評価の一例を表 6 に示す. 表中の 1 から 5 が各評価項目の番号に対応し，その下 に記載してあるアルファベットが，その項目に対する 評価になる。また，「自己評価」の欄には達成度パー セントが記入されている。評価者は，このような評価 を分析対象のデー夕に対して順次おこなっていく.

\section{4. 分析結果}

技術者倫理ポートフォリオ・システムの運用は平成 21 年度より開始され，今回はこの平成 21 年度分のデー 夕についての分析・評価をおこなった．なお，分析対 象となるデー夕の抽出作業は筆者がおこない，その データの分析を外部委託した，その後，表 6 のような 形式で返送された分析結果のデー夕を筆者があらため て集計してグラフ化した。

ここで，分析結果を詳細に考察するためには，学内 の事情（学部学科の編成や具体的な授業内容など）に ついての知識を要する。これは実際の FDにとっての み有用なことであり，本論文でその詳細な解説をおこ なうことは不適当であろう。ここでは，分析結果のわ かりやすい一例を示して, 技術者倫理ポートフォリオ という方法の可能性について論じることにしたい.

具体的な分析結果グラフの一例を図 2 に示す。これ は，学部学科等の所属に関係なく, 評価項目「(1) 価 值観と文化の多様性を理解している」についての全学 生の有効評価における (A) から (D) の割合 (\%)をグ ラフ化したものである.

この分析結果は，あくまで自己評価レポートに基づ く限定的な評価である。 そのため, とくに現時点では, 絶対的な評価ではなく，相対的な評価として考察する 必要がある．例えば，全体的な傾向として評価の低 さ（C判定の多さ）が伺える.この理由として, 判定 の絶対的な基準が高かったことも考えられるし，分析 に用いた自己評価レポート・ポートフォリオの記述が そもそも評価の対象としては短く不十分であったこと も考えられる。また，実際の教育内容と評価項目とは 基本的に一致しているわけではないため, 評価項目そ のものがこのような結果を生じさせる根本的な原因に なっていることも考えられる。 また，今回の評価は 平成21年度に実施した科目のみに対する評価であり, 同一の母集団を対象とした経年変化について評価して

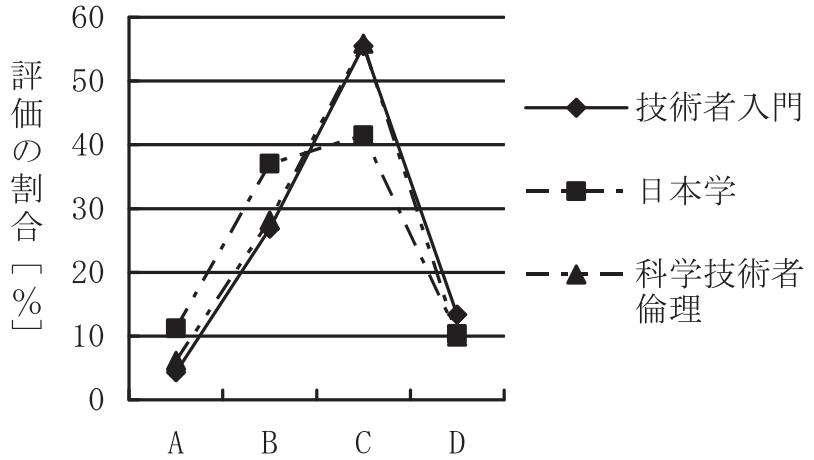

図 2 価值観と文化の多様性（設問固定型抽出）

いるわけではないことにも注意する必要がある.

ただし，このような注意点を踏まえても，例えば今 回の評価は広義の解釈であれ, 技術者倫理に基づく評 価項目を設定しながら「科学技術者倫理」の評価が十 分に高くなっていないことには検討の余地があるだろ う.この結果からは, 現在の「科学技術者倫理」の教 育内容では価值観と文化の多様性を重視した教育が不 十分である可能性が伺える. そのため, 現在の「科学 技術者倫理」の教育内容では, AHELOやDeSeCoへ の対応としては不十分である可能性も指摘できる.

すなわち, 教育プログラム全体として今回の評価項 目を重視して，価值観と文化の多様性への配慮につい て発展的な教育を目指すのであれば，「科学技術者倫 理」の教育内容をその方針のもとに変更するか，ある いは開講時期を変更するといった対応が検討されるべ きということになる。

また，これ以外の興味深い結果としては，例えば $\lceil(5)$ 責任感を有している」に対する「日本学」の評 価が相対的に高かったことがあげられる。この結果か らは，「技術者」や「責任」を前面に押し出した教育 内容では内容が限定的になり, 媣い理解には不十分に なっている可能性も考えられる。 そして, 直接的な内 容ではなくても, 関心の持てる特定の社会的なテーマ について考察を深めることが有効である可能性が考え られる。そそうすると，大学再編の動きの中で批判の対 象とされてきた「一般教養」科目のような教育内容の 意義を再評価すべきということにもなるだろう.

もちろん，ある科目が「一般教育」として不十分で あるとしても，その是非は課程全体の教育方針によっ て判断が分かれる問題である. 多様性のある「一般教 
育」を重視するか，それとも限定的な「専門教育」を 重視するか，あるいは現状のバランスを最適とするか という判断は, 各大学における教育プログラム全体の バランスに関する議論である。これは，AHELOなど の高等教育の国際標準に準拠していくことを求める か，それともローカルな独自の基準に特化するかとい う選択にも関連しており，もちろん現状が最善である という判断もありうる。

以上の考察で示されるように, 技術者倫理ポート フォリオを用いて教育プログラムの評価をおこなうこ とは, その教育プログラム全体の構成を検討していく 上で有効であることがわかる.

\section{5. 現時点の問題}

もちろん, 現時点ではこの技術者倫理ポートフォリ オによる評価の信頼性は十分なものではない.一般に, 自己評価レポート・ポートフォリオの設問回答におけ る論述は文字数が少なく，それを別の評価項目で評価 するには判断の根拠が不十分になりがちである.また, 外部委託した評価者の教育内容への理解が不十分であ るという問題もある。これは外部評価には内部事情に 対する理解がどの程度まで必要であるかという外部評 価に対する根本的な問題として残される. そのため, この方法は現状では補助的な判断材料にしかならない ことも確かである.

そもそも，今回の方法は質的評価をおこなうために 複数の方法を用いるトライアンギュレーション (triangulation）の一つとして実施したものである.この特 色 GPプロジェクトでは, 他にも履修者に対するフォー カス・グループ・インタビューや授業内で実施した課 題の分析などによる評価もおこなっている。この技術 者倫理ポートフォリオは, 教育プログラム全体を評価 する上で参考となる一つの方法に過ぎないものとして 位置づけられている。

このような信頼性の向上という課題の他に, 外部委 託を抢こなうことによる費用の増大という問題もあ る。評価が定性的なものであるため, 現状では十分な 量のデータや細かな評価基準を処理できないし，IRR のために複数の評価者に依頼するため, さらに費用対 処理件数は減少してしまう。

以上のように，この方法は判断の手掛かりとしては 有効である。しかし, 費用対効果が十分ではなく, 継 続的に実施していくことは難しいのが現状である.

\section{6. おわりに}

本論文の冒頭で述べたように，教育の質評価への社
会的な要求は高まっており, アウトカム評価のための 方法の開発が必然的に求められていくだろう。 そのた めには本論文で提示したようなポートフォリオを用い た分析・評価方法は有効な手段の一つになりうる. 技 術者倫理ポートフォリオは, 現時点での金沢工大で利 用可能であった資源を活用して開発した一つの方法で あり，さまざまな改善の余地がある，今回は新しい方 法の開発であったため, 費用対効果も低く, 不十分な 点も多い. しかし, このような試行錯誤は新しい方法 を開発していく上で必要不可欠のものであるとも考え られる。本論文で示した方法の問題と可能性がさらな る方法の改善へと活用され, よりよい教育の実現に結 びついていくことを期待したい.

\section{謝辞}

本研究は平成19年度特色ある大学教育支援プログラ ム「価值の共有による技術者倫理教育」の助成を受け ておこなわれた，開発にあたっては，金沢工業大学基 礎教育部の札野順教授および藤本元啓教授をはじめと する関係者に評価項目についてのご助言をいただい た。また，偐アドレスの関係諸氏には，この方法を実 施するにあたって評価作業の実際的な観点からさまざ まなご意見をいただいた。

\section{参 考 文 献}

1 ) 羽田貴史, 米澤彰純, 杉本和弘編著: 高等教育質保 証の国際比較, 東信堂, pp.3-100, 2009

2) 同上, pp.239-64

3 ) G.M. Rogers and T. Chow : Electric Portfolios and the Assessment of Student Learning, T.W. Banta ed., Portfolio Assessment, Jossey-Bass, pp. $19-24,2003$

4 ）金沢工業大学平成18年度特色GP報告書作成グ ループ: 学ぶ意欲を引き出すための教育実践, 金 沢工業大学, 2009

\section{著 者 紹 介}

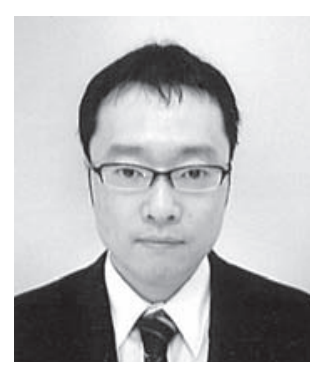

夏目 賢一

1997年金沢大学理学部物理学科卒業 2006年東京大学大学院総合文化研究科博 士課程単位取得満期退学

現在, 金沢工業大学基礎教育部講師

日工教, 技術者倫理調查研究委員会委員

日本科学史学会, 日本物理学会などに所属 